\title{
ARTIKELEN
}

\section{De preparatie op de nafase binnen veiligheidsregio's}

\section{Een verkennend onderzoek}

Martine de Bas, Ira Helsloot \& Michel Dückers

In dit artikel wordt stilgestaan bij kenmerken waaraan de preparatie op de nafase van rampen en crises volgens literatuur en normdocumenten dient te voldoen. In veiligheidsregio's is de preparatie per kenmerk in de praktijk geïnventariseerd. Er blijkt sprake van aanzienlijke regionale variatie in preparatie. Met name de betrokkenheid van burgers en partners bij de planvorming en de aansluiting bij het risicoprofiel verdienen aandacht. De uitdaging voor de preparatie op de nafase is dat optimalisatie moet plaatsvinden in een dagelijkse context met betrekkelijk lage prioriteit (andere problemen vragen aandacht van bestuur en politiek) en schaarste aan calamiteiten (weinig kans om te leren of routine te verwerven). Meer kennis over de relatie tussen randvoorwaarden, mate van preparatie en kwaliteit van dienstverlening is noodzakelijk om gericht te kunnen investeren.

\section{Introductie}

Nederland wordt regelmatig geconfronteerd met (mini)crises en gebeurtenissen die overheidsoptreden vergen (Berghuijs et al. 2000; Laurier et al. 2012; Gouweloos et al. 2013; Van Duin et al. 2013; Van Duin en Wijkhuijs 2014). Dit artikel richt zich op de voorbereiding op de periode na de crisis die in het teken staat van herstel en nazorg. Over deze 'nafase' is meermaals geconstateerd dat het een onderbelichte schakel is binnen de crisisbeheersing (Taskforce Management Overstromingen 2009; Zannoni 2010; Ministerie van Veiligheid en Justitie 2012).

\subsection{Onderzoeksdoel}

Lokale plannings- en besluitvormingsprocessen vormen het fundament voor de inrichting van nazorg en herstel bij rampen (Geis 1996; Petterson 1999). Hoewel het belang van preparatie op de nafase beleidsmatig niet ter discussie staat (Ministerie van Veiligheid en Justitie 2012), is er geen samenhangend beeld over gewenste en feitelijke kenmerken van de preparatie, de hierbij behorende randvoorwaarden en de staat ervan in Nederland. Deze studie is bedoeld om hier meer inzicht in te krijgen en te onderzoeken of er sprake is van een probleem ten aanzien van de preparatie op de nafase. Bij preparatie op de nafase kan een onderscheid worden gemaakt in preparatie in de 'koude' fase (zonder daadwerkelijke 
crisis) en voorbereidingen in de 'warme' fase (tijdens een crisis) op de onvermijdelijke nafase. Dit artikel focust op nafasepreparatie, toegespitst op bevolkingszorg en psychosociale hulp in de koude fase binnen de veiligheidsregio; het niveau waar volgens de Wet Veiligheidsregio's de verantwoordelijkheid voor de regionale planvorming is belegd. Eerst wordt een model uitgewerkt om de preparatiepraktijk te beschrijven en te verklaren, gebruikmakend van literatuur en normdocumenten, zoals richtlijnen, visiedocumenten en wetgeving. Daarna wordt de planvorming voor de nafasepreparatie binnen veiligheidsregio's in Nederland afgezet tegen het model waarbij in de discussie dieper wordt ingegaan op relevante randvoorwaarden en het belang van meer onderzoek.

\section{Literatuurverkenning: preparatiekenmerken}

Vooruitdenken stelt in staat te anticiperen op problemen die op korte en lange termijn kunnen ontstaan bij herstel en nazorg na een calamiteit (Rubin en Barbee 1985; Quarantelli 1989; Kennedy et al. 2008; Boin en 't Hart 2010; Smith 2010). Uit bestuurskundige en organisatiewetenschappelijke literatuur is een aantal randvoorwaarden en procesmatige kenmerken af te leiden die in combinatie een samenhangend referentiekader vormen voor onderzoek naar nafasepreparatie. In eerder internationaal onderzoek zijn de kenmerken van een zogenoemd 'planning and delivery system' voor de nazorg bij rampen in kaart gebracht in Europa door middel van een Delphi-onderzoek onder experts (Bisson et al. 2010) en een vragenlijstonderzoek onder 286 betrokkenen bij nazorg vanuit beleid, praktijk en wetenschap in circa dertig landen (Witteveen et al. 2012; Dückers et al. 2015). In een goed werkend systeem is bij de planvorming en uitvoering sprake van gecoördineerde interprofessionele samenwerking tussen professionals, (getrainde) vrijwilligers en autoriteiten van verschillende organisaties, en is de planvorming gebaseerd op evidence-based richtlijnen, geïntegreerd in een samenhangend plan dat wordt gefaciliteerd door wet- en regelgeving; een plan bovendien dat periodiek wordt geëvalueerd ter borging van de continuïteit (Dückers et al. 2015). Tegen deze achtergrond is een aantal kenmerken, hierna nader toegelicht, van belang:

- samenhang planvorming;

- borging en continuïteit;

- evaluatie en leren;

- betrokkenheid burgers;

- betrokkenheid partners;

- deskundige medewerkers.

Het kenmerk 'gecoördineerde interprofessionele samenwerking' is meegenomen in samenhang planvorming en betrokkenheid van burgers en partners. 


\subsection{Kenmerken}

\section{- Samenhang planvorming}

De samenhang van de planvorming is onder te verdelen in meerdere punten. Is er een plan, in hoeverre vertonen de door wet- en regelgeving opgelegde bouwstenen van de planvorming samenhang (gebaseerd op beleidsplan, aansluitend op risicoprofiel), en hoe breed is de voorgeschreven thematiek uit richtlijnen en prestatieeisen meegenomen?

De vraag of er een plan is, het eerste punt, kan met ja of nee worden beantwoord. De vraag naar samenhang in wettelijke bouwstenen en aanbevolen thematiek verdient wat meer uitleg. In de Wet Veiligheidsregio's (2010) wordt aangestuurd op samenhang tussen een op te stellen risicoprofiel, beleidsplan en een regionaal crisisplan. In het risicoprofiel worden regionale risico's inzichtelijk gemaakt. Het regionaal crisisplan beschrijft de generieke, regionale aanpak van rampen en crises. In de planvorming ligt de verantwoordelijkheid bij de veiligheidsregio, een daadwerkelijke nafase wordt uitgevoerd onder regie van de betrokken gemeente. In de Wet Publieke Gezondheid (VWS 2008, art. 2) is opgenomen: '(...) het college van burgemeester en wethouders bevordert de totstandkoming en de continuïteit van en de samenhang binnen de publieke gezondheidszorg en de afstemming ervan met (...) de geneeskundige hulpverlening bij ongevallen en rampen'. Om dit te bewerkstelligen moeten colleges van burgemeester en wethouders zorgdragen voor 'het bewaken van gezondheidsaspecten in bestuurlijke beslissingen' en 'het bevorderen van psychosociale hulp bij rampen'. Het volgende punt gaat over de thema's die terugkeren in de planvorming. Hoe meer nafasethema's op voorhand goed doordacht zijn, hoe beter de kans op efficiëntie en 'kwaliteit' van de besluitvorming na de gebeurtenis (Geis 1996; Petterson 1999). Verschillende publicaties gaan in op te adresseren thema's binnen de nafase (Berghuijs 2000; Van Duin en Zannoni 2005; Ammerlaan 2009; Helsloot et al. 2009; Zannoni 2010; Boin en 't Hart 2010; Hoijtink en Jong 2011; Ministerie van Veiligheid en Justitie 2012; GROOTER 2012; Laurier et al. 2012; Gouweloos et al. 2013; Van Duin et al. 2013; Van Duin et al. 2014; Impact 2014; Gemeente Moerdijk 2014). Aangezien dit onderzoek zich toespitst op bevolkingszorg en psychosociale hulp, is relevant dat beide themagebieden terugkeren in de preparatie. Uit 'Bevolkingszorg op Orde' (Commissie Bruinooge) en de 'Multidisciplinaire richtlijn psychosociale hulp bij rampen en crises' (Impact 2014) zijn de volgende thema's af te leiden: informatie en coördinatie, communicatie, registratie (doden, gewonden en overige getroffenen), verwanteninformatie, één-loketfunctie, vaste gemeentelijke contactpersonen voor getroffenen, opvang, rouwverwerking, samenwerking met partners op lokaal, (inter)regionaal en/of (inter)nationaal niveau (kenmerkend voor een goed functionerend nazorgsysteem; later meer hierover), monitoren (maatschappelijke) onrust, juridische afwikkeling, financiën, herstel, strafrechtelijk onderzoek, politiek-bestuurlijke aspecten, onderzoek en evaluatie (eveneens een kenmerk van een goed functionerend nazorgsysteem), verantwoording en zorg voor eigen medewerkers. Het is een brede reeks thema's die, zoals later toegelicht, wordt meegenomen in het verkennende onderzoek onder veiligheidsregio's. 


\section{- Borging en continuïteit}

De preparatie op de nafase begint in de warme fase als een soort tijdelijk project om te anticiperen op een probleem dat er voorheen niet was, namelijk de impact en gevolgen van rampen. Uiteindelijk zal de dienstverlening, met het verstrijken van de tijd, worden ondergebracht bij reguliere beleidsterreinen. Maatregelen om de continuïteit te bevorderen zijn gewenst, met name zodra er sprake is van overgangsmomenten en overdracht. Organisatorische structuren, werkwijzen en systemen zullen daartoe moeten worden ingericht (Petterson 1999; Barendse 2008).

\section{- Evaluatie en leren}

Benadrukt is al dat in een goed werkend systeem voor de planning en uitvoering van de nazorg bij rampen sprake is van evaluatie van de planvorming (Dückers et al. 2015). Dit betekent dat de preparatie op de nafase vraagt om een kwaliteitssysteem. Daarvan is sprake als partijen samenwerken om te zorgen dat aan prestatie-eisen en richtlijnen van een sector/professie (Commissie Bruinooge 2002; Impact 2014) wordt voldaan en de voortgang bewaken. Het kwaliteitssysteem van de nafase kan niet werken zonder een samenhangende realisatie van de kenmerken. Onderzoek toont dat de ontwikkeling van kwaliteitssystemen verschillende fasen doormaakt en dat externe druk op organisaties de ontwikkeling stuurt (Wagner et al. 1999; Dückers et al. 2009). Ook veiligheidsregio's moeten een kwaliteitssysteem hanteren (Wet Veiligheidsregio's, art. 23).

Een gangbaar kwaliteitsmodel is het zogenoemde plan-do-study-act model (Langley et al. 1996; Taylor et al. 2014). Door continue de stappen van het kwaliteitsmodel te doorlopen wordt duidelijk hoe gepland beleid uitpakt en of de kwaliteit vraagt om bijsturing, ook voor de nafase (Impact 2014; Dückers en Thormar 2015).

\section{- Betrokkenheid burgers en partners}

Meerdere partijen zijn betrokken bij uitvoeringsprocessen tijdens de nafase. Het gaat om burgers en andere partners zoals de GGD, het Rode Kruis en Slachtofferhulp Nederland. Indien zij in de koude fase samenwerken in de planvorming, kunnen verwachtingen en wensen op voorhand worden verkend.

Op voorhand zijn de gevolgen en dus ook de bijpassende herstel- en nazorgactiviteiten na een ramp niet bekend. Toch voorzien gezichtspunten van burgers in een toetssteen of de preparatie aansluit bij doelgroepen en hun redelijke verwachtingen. Het past bovendien bij het huidige beleidsdiscours waarin nadruk ligt op eigen capaciteiten en vermogens van burgers (Muller et al. 2009; Groenewegenter Morsche en Oberijé 2010; Boin en 't Hart 2010; Helsloot et al. 2010; Leferink 2010; Dückers en Pröpper 2011; Helsloot en In 't Veld 2014). Aangenomen wordt dat burgers gevolgen van rampen en crises veelal op eigen kracht het hoofd kunnen bieden, zeker als zij zijn voorbereid op de gevolgen en de aanpak ervan (Petterson 2009; Bonanno et al. 2010; Boin en 't Hart 2010; Helsloot et al. 2010; Kerstholt 2013; Impact 2014; Boin en Bynander 2015). De boodschap van zelfredzaamheid uitdragen is één ding, het inrichten van de traditioneel hiërarchisch opgezette overheid om de zelfredzaamheid en veerkracht van burgers daadwerkelijk te benutten is een tweede. Deels wordt het samenspel tussen actoren - over- 
heden, burgers en bedrijven - in de praktijk gehinderd door cultuurverschillen (Douglas en Wildavsky 1982; Van Caem 2008; Helsloot et al. 2010; RMO 2013). Betrokkenheid van burgers draagt bij aan de kwaliteit en legitimatie van overheidsbesluiten, de opbouw van de samenleving en haar sociaal kapitaal (Pröpper en Steenbeek 2001; Barnes et al. 2003). Het samenspel met burgers en de ruimte die het bestuur biedt, zijn terug te voeren op de 'grondhouding' van het bestuur: ligt het initiatief bij burgers, overheden of allebei en wat is er te zeggen over de wijze waarop hieraan uitvoering gegeven wordt (Dückers en Pröpper 2011)?

De variëteit aan thema's geeft aan dat veiligheidsregio's en gemeenten in de nafase afhankelijk zijn van inzet van partners (Petterson 1999; Kennedy et al. 2008; Zannoni 2010; Boin en 't Hart 2010; Dückers et al. 2014; Ministerie van Veiligheid en Justitie 2012). Tijdens de preparatie zal een inschatting moeten worden gemaakt van benodigde (externe) partners, rekening houdend met risicoprofiel en beleidsplan. Zowel voor structurele relaties als gelegenheidsverbanden (beide kunnen relevant zijn binnen de nafase) zijn randvoorwaarden voor netwerken en interorganisatorische samenwerking, inclusief de regierol van het lokaal bestuur, van toepassing. Te denken valt aan gezagvolle coördinatie, overeenstemmingen over doelen en middelen en afhankelijkheidsbesef (zie ook Koppenjan en Klijn 2004; Terpstra en Kouwenhoven 2004; Boin en 't Hart 2010).

\section{- Deskundige medewerkers}

Een gedachte is dat zodra taken tijdens de nafase passen bij de dagelijkse werkzaamheden, opleiden, trainen en oefenen (OTO) tot een minimum kunnen worden beperkt (zie bijvoorbeeld Scholtens 2007). Los van de vraag of het daadwerkelijk mogelijk is om de nafasedynamiek voldoende onderdeel te laten zijn van de dagelijkse praktijk, vergt de mate waarin thema's uit sleuteldocumenten adequaat worden meegenomen in de preparatie deskundige medewerkers. Mensen dienen te beschikken over de juiste motivatie, capaciteit en gelegenheid (Michie, Van Stralen en West 2011), denk hierbij aan enthousiasme, overtuiging, kennis en ervaring, vaardigheden en talenten, maar ook voldoende tijd, benodigde middelen en draagvlak (zie ook Grooter 2012; Impact 2014). Een goed ingerichte OTOstructuur wordt in dit verband onmisbaar geacht.

\subsection{Model}

Ten aanzien van preparatie op de nafase kunnen in ieder geval twee niveaus worden onderscheiden (zie tabel 1). Bij het eerste niveau is er nauwelijks sprake van samenhangende activiteiten en geen oog voor lokale risico's en evaluatie van het niet-geïntegreerde plan. Planvorming en oefenpraktijk zijn hoogstens gericht op (individuele functionarissen binnen) de eigen organisatie en bestrijken een beperkt aantal thema's (smal). De interne blik is terug te zien in beperkte betrokkenheid van netwerkpartners en burgers. Bij het tweede niveau is sprake van een systematische, multidisciplinaire en integrale aanpak (breed qua thematiek), waarbij burgers en partners actief betrokken zijn. Er wordt rekening gehouden met lokale risico's, en behoeften, problemen en vermogens van burgers. Ook wordt met partijen geëvalueerd na incidenten. 
Tabel 1 Preparatie op de nafase: twee niveaus en kenmerken*

\begin{tabular}{|c|c|c|}
\hline Kenmerk & $\begin{array}{l}\text { Niveau I: Oriëntatie en } \\
\text { bewustwording }\end{array}$ & $\begin{array}{l}\text { Niveau 2: Borging en inte- } \\
\text { gratie }\end{array}$ \\
\hline Samenhang planvorming & $\begin{array}{l}\text { Plan aanwezig, uitgewerkt in } \\
\text { relatie tot beleidsvisie en lokale } \\
\text { risico's } \\
\text { Smal: primair gericht op eigen } \\
\text { kernthema's (bijvoorbeeld } \\
\text { bevolkingszorg) }\end{array}$ & $\begin{array}{l}\text { Planvorming uitgewerkt in rela- } \\
\text { tie tot beleidsvisie en lokale } \\
\text { risico's } \\
\text { Breed; andere kernthema's cri- } \\
\text { sisbeheersing meegenomen in } \\
\text { planvorming }\end{array}$ \\
\hline Borging en continuïteit & Niet uitgewerkt & Uitgewerkt \\
\hline Evaluatie en leren & $\begin{array}{l}\mathrm{Na} \text { incidenten geen evaluatie van } \\
\text { planvorming }\end{array}$ & $\begin{array}{l}\mathrm{Na} \text { incidenten evaluatie van } \\
\text { planvorming (PDSA) }\end{array}$ \\
\hline Betrokkenheid burgers & Burgers niet betrokken & $\begin{array}{l}\text { Burgers betrokken bij planning } \\
\text { en evaluatie }\end{array}$ \\
\hline Betrokkenheid partners & Partners niet betrokken & $\begin{array}{l}\text { Partners betrokken bij planning } \\
\text { en evaluatie }\end{array}$ \\
\hline Deskundige medewerkers & $\begin{array}{l}\text { Niet uitgewerkt of in monodisci- } \\
\text { plinair verband }\end{array}$ & $\begin{array}{l}\text { Uitgewerkt in multidisciplinair } \\
\text { verband }\end{array}$ \\
\hline
\end{tabular}

* Geïnspireerd door Wagner et al. (1999); Dückers et al. (2009)

\section{Methode}

In dit artikel wordt de stand van zaken met betrekking tot de planvorming van preparatie op de nafase bij alle 25 veiligheidsregio's in Nederland afgezet tegen het model. Voor het onderzoek is gekozen voor een combinatie van documentenonderzoek en veldonderzoek middels halfgestandaardiseerde interviews. Ten eerste is een inventarisatie uitgevoerd van de openbaar beschikbare planvorming van preparatie op de nafase. Daarna zijn in de periode november 2013 tot januari 2014 telefonische interviews gehouden met de opstellers of verantwoordelijken voor de planvorming, veelal coördinatoren bevolkingszorg. De vragenlijst bevat deels gestandaardiseerde en deels open vragen. De onderzoekers hebben voor aanvang van het interview aangegeven dat het onderzoek anoniem is en bedoeld is om een beeld te krijgen van de actuele planvorming op het gebied van de preparatie op de nafase. Door de gehele onderzoekspopulatie van 25 veiligheidsregio's te betrekken is de externe validiteit van dit onderzoek gewaarborgd. De data zijn gecategoriseerd volgens de preparatiekenmerken: samenhang planvorming, borging en continuïteit, evaluatie en leren, betrokkenheid burgers en partners, en deskundige medewerkers.

\section{Resultaten}

\subsection{Scores per kenmerk}

- Samenhang planvorming

In nagenoeg iedere regio is een plan opgesteld. In $12 \%$ van de veiligheidsregio's is de planvorming voor de preparatie op de nafase uitgewerkt in scenario's, geba- 
seerd op het regionale risicoprofiel. In bijna de helft (44\%) van de onderzochte regio's is de planvorming voor de preparatie op de nafase uitgewerkt in het beleidsplan.

In de planvorming worden de thema's 'één-loketfunctie' (76\%), 'communicatie', 'hulpverlening' (74\%), 'informatie en coördinatie' en 'schademanagement' (72\%), en 'rouwverwerking en herdenking en monumenten' (68\%) het meest genoemd. Regelmatig wordt ook genoemd 'registratie van overige getroffenen' (48\%). ${ }^{1}$ Minder vaak komen voor: 'zorg voor eigen medewerkers', 'regionale, interregionale, nationale en/of internationale samenwerking', 'politiek-bestuurlijke aspecten', en 'monitoren van (maatschappelijke) onrust' (alle 36\%), en 'vaste gemeentelijke contactpersonen voor getroffenen' (24\%). Zodra met de thema's een gezondheidsbelang is gediend, dan worden ze in de praktijk opgepakt in samenwerking met de GGD.

\section{- $\quad$ Borging en continuïteit}

Minder dan een kwart van de veiligheidsregio's heeft de nafase geborgd binnen reguliere gemeentelijke processen in de planvorming. In circa een derde (36\%) van de veiligheidsregio's is de nafase geborgd als een apart project (dus niet onderdeel van de reguliere gemeentelijke processen) en $40 \%$ heeft de borging van de nafase niet beschreven.

In $38 \%$ van de veiligheidsregio's is voorbereiding op continuïteit van de gemeentelijke organisatie een punt van aandacht. De meerderheid (62\%) heeft het onderwerp niet opgenomen in de voorbereiding op de nafase.

\section{- Evaluatie en leren}

Alle veiligheidsregio's geven aan incidenten te evalueren, in bijna de helft (48\%) van de regio's wordt ook de preparatie op de nafase standaard geëvalueerd. Twee derde hiervan (65\%) evalueert de opstart van het proces. In $24 \%$ van de gevallen richt de evaluatie zich op andere zaken, zoals de nazorg aan de betrokken hulpverleners. Een aantal respondenten geeft aan dat slechts geëvalueerd wordt als de te evalueren casus hiertoe aanleiding geeft. Het delen van (de beperkte, want weinig voorkomende) ervaringen wordt door respondenten van groot belang geacht om te leren.

\section{- Betrokkenheid burgers en partners}

Uit het onderzoek blijkt dat $20 \%$ van de veiligheidsregio's in de planvorming beschreven heeft burgers te betrekken bij het opstellen van een plan van aanpak voor de nafase. In $80 \%$ van de veiligheidsregio's zijn burgers niet betrokken bij de planvorming.

1 Kanttekening die gemaakt moet worden bij de registratie van overige getroffenen is dat een groot aantal respondenten aangeeft dat in de loop van 2014 het Centraal Registratie Informatie Bureau (CRIB) zal verdwijnen en slachtofferinformatiesystematiek (SIS) een groot deel van deze taak zal overnemen. SIS beperkt zich tot doden en zwaargewonden, terwijl de potentiële doelgroep groter is (Dückers en Sardemann 2014). 
In $16 \%$ van de veiligheidsregio's zijn externe partijen betrokken bij de planmatige voorbereidingen op de nafase (bij de helft gaat het om het vragen van feedback op conceptplannen). In bijna de helft (44\%) van de regio's werd een andere vorm van betrokkenheid gekozen, zoals netwerkbijeenkomsten en oriënterend oefenen met partners. $40 \%$ heeft op geen enkele wijze externe partijen betrokken bij de voorbereidende planvorming.

\section{- Deskundige medewerkers}

In slechts $20 \%$ van de veiligheidsregio's is de preparatie op de nafase onderdeel van de multidisciplinaire OTO-cyclus. Diverse regio's geven aan te worstelen met de organisatie en de personele invulling van het proces. Vooral de samenhang tussen andere processen, taken en verantwoordelijkheden van interne maar vooral ook externe partners roept binnen een aantal regio's nog veel vragen op.

\subsection{Voorlopers en achterblijvers}

Figuur 1 laat de scores per kenmerk zien in de vorm van een spinnenweb. Het gemiddelde van de vijf regio's met de hoogste en laagste preparatiescore is weergegeven. In het spinnenweb worden de resultaten afgezet tegen genoemde indicatoren om de mate van voorbereiding te kunnen bepalen. Het verschil in score tussen regio's zit vooral in de aandacht voor planvorming op basis van het beleidsplan en evaluaties. Gemiddeld scoort de aanwezigheid van planvorming het hoogst; de aansluiting bij het regionale risicoprofiel en de betrokkenheid van burgers scoren gemiddeld het laagst.

\section{Discussie en aanbevelingen}

Dit onderzoek geeft een beeld van kenmerken waaraan de preparatie nafase zou moeten voldoen, uitgaande van bestaande literatuur en normdocumenten. Op basis daarvan is verkend in welke mate veiligheidsregio's in hun planvorming aan dergelijke kenmerken voldoen. Dat blijkt wisselend en soms slechts in beperkte mate het geval te zijn. Qua fasering bevinden de veiligheidsregio's zich overwegend op het niveau van 'oriëntatie en bewustwording' en - een aantal uitzonderingen daargelaten - nog niet op het niveau waarin kenmerken in samenhang een systematische werkwijze weerspiegelen: 'borging en integratie'. Er is nog de nodige winst te behalen op preparatievlak, bijvoorbeeld op het gebied van opleiden, trainen en oefenen, continuïteit en evaluatie. In het oog springt ook dat zowel burgers als professionele partners in de meeste veiligheidsregio's niet of nauwelijks worden betrokken bij de planvorming, waardoor het beeld ontstaat van een beperkt ketenbewustzijn en een sterk intern gerichte overheid. Het werken in netwerkorganisaties en het stimuleren van zelfredzaamheid van burgers ('de participatiesamenleving') zijn belangrijke pijlers van hedendaags overheidsbeleid.

Dit zijn belangrijke zaken om in de praktijk aan te gaan werken. Dat is een eerste aanbeveling die samengaat met een tweede aanbeveling. Ondanks dat er aanzien- 


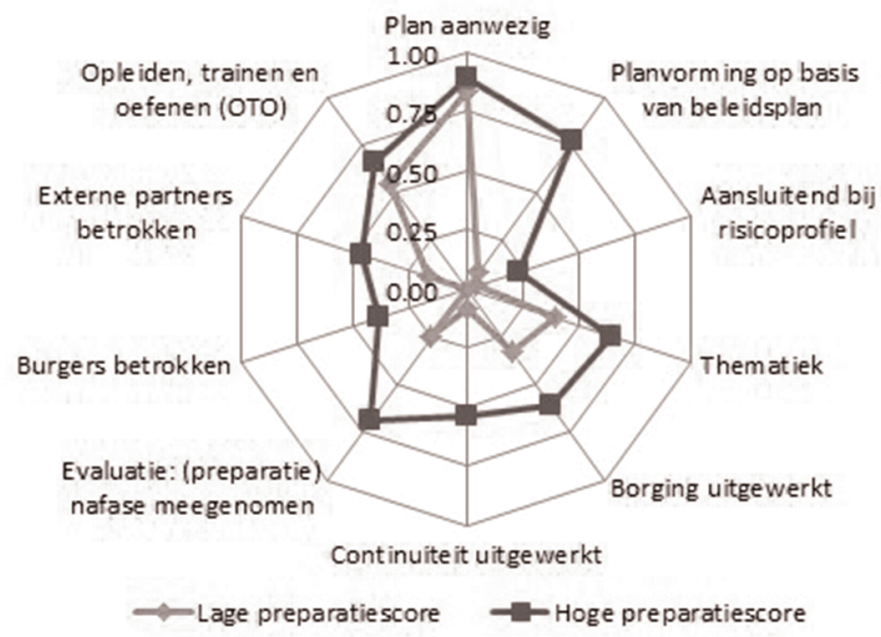

Toelichting op de scores: Plan aanwezig $(0=$ nee, 0,5 = in ontwikkeling, $1=j a)$, Planvorming op basis van beleidsplan ( 0 indien nee, 1 indien ja), Aansluiting risicoprofiel ( 0 indien geen scenario's, 0,5 indien scenario's, 1 indien scenario's gebaseerd op risicoprofiel), Thematiek (0 indien geen thema's, 1 indien alle thema's), Borging uitgewerkt ( 0 indien nee, 0,5 indien ambtelijk of bestuurlijk, 1 indien ambtelijk en bestuurlijk), Continuïteit uitgewerkt ( 0 indien niet in plan beschreven, 0,5 indien als aandachtspunt genoemd, maar niet nader uitgewerkt, 1 als concreet uitgewerkt), Evaluatie: bij evaluatie incidenten wordt (preparatie) nafase ook meegenomen ( 0 indien niet, 1 indien ja), Burgers en bedrijven betrokken ( 0 indien niet, 1 indien ja), Externe partners betrokken ( 0 indien niet, 1 indien ja), OTO (0 indien niet, 0,5 indien monodisciplinair, 1 indien multidisciplinair). Veiligheidsregio's zijn ingedeeld in de groep 'hoge preparatiescore' indien de preparatiescore - de kenmerken opgeteld en gedeeld door tien - gelijk aan of hoger is dan het gemiddelde. In geval van een preparatiescore beneden het gemiddelde is de veiligheidsregio ingedeeld in de groep 'lage preparatiescore'.

\section{Figuur 1 Gemiddelde preparatiescores op de nafase: vergelijking voorlopers en achterblijvers}

lijke verschillen zijn vastgesteld tussen veiligheidsregio's in de mate van preparatie - er zijn voorlopers en achterblijvers - kunnen deze verschillen nog niet worden verklaard. Het is belangrijk hier wel zicht op te krijgen, ook om na te kunnen gaan in hoeverre specifieke investeringen proportioneel zijn.

\section{Vervolgonderzoek}

Het model dat op basis van literatuur en normdocumenten is opgesteld, biedt een vertrekpunt voor meer systematisch onderzoek naar de stand van zaken op het gebied van de preparatie op de nafase en de randvoorwaarden die daarbij een rol spelen. Een verkennend onderzoek zoals het huidige biedt inzicht in variatie die onder veiligheidsregio's bestaat waar het aankomt op de preparatie op de nazorg. In figuur 2 is de veronderstelde samenhang weergegeven tussen de toestand van de preparatie (midden; zoals bestudeerd in dit onderzoek), randvoorwaarden die 


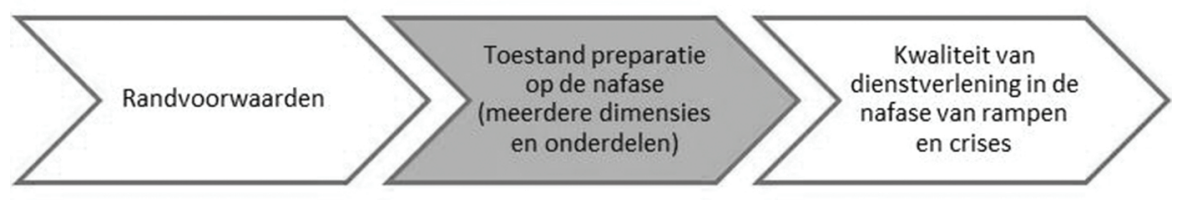

\section{Figuur 2 Veronderstelde samenhang tussen randvoorwaarden, preparatietoestand en kwaliteit van nazorg en herstel}

daarvoor bepalend zijn (links; later meer hierover) en de kwaliteit van uiteindelijke dienstverlening die pas vast te stellen is zodra sprake is van een calamiteit (rechts; later meer hierover). Aangenomen wordt dat beïnvloeding van de juiste randvoorwaarden een betere preparatie mogelijk maakt (hogere preparatiescore; zie de kenmerken in de tabel en het spinnenweb) en dat dit leidt tot een hogere kwaliteit van dienstverlening zodra zich werkelijk een ramp voordoet. Het is wenselijk om de veronderstelde samenhang te toetsen. Dat kan kwantitatief, maar bij voorkeur in combinatie met kwalitatieve onderzoeksmethoden om mechanismen in beeld te brengen.

\section{Randvoorwaarden}

Er is weinig bekend over randvoorwaarden die een rol spelen bij de preparatie op de nafase en de mogelijkheid om deze te beïnvloeden. Vervolgonderzoek kan zich verder toespitsen op randvoorwaarden op verschillende niveaus in de koude én de warme fase, uiteenlopend van juridisch, economisch, politiek-bestuurlijk, sociaalcultureel tot psychologisch. Kennis van randvoorwaarden voor de preparatie op de nafase is nuttig om deze te kunnen beïnvloeden. Het is aannemelijk dat de mogelijkheid om randvoorwaarden te beïnvloeden afneemt naarmate het schaalniveau toeneemt. Op het niveau van een land laten randvoorwaarden zich minder goed beïnvloeden en als dat al mogelijk is, alleen tegen aanzienlijke maatschappelijke kosten. Realistischer is om gericht te investeren op de lokale omgeving van individuen. Dit individuele niveau is het niveau waarop in Europa in een recente studie de meeste variatie en verbeterruimte is aangetroffen (Dückers et al. 2015). De huidige studie wijst op variatie tussen veiligheidsregio's in Nederland.

Vervolgonderzoek gericht op het in beeld krijgen van de randvoorwaarden voor de lokale preparatie op de nafase is potentieel waardevol als dit kennis voor verbetering oplevert: aan welke knoppen moet worden gedraaid voor het meest optimale effect?

Dat geldt in het bijzonder voor randvoorwaarden die samenhangen met het gedrag van betrokkenen bij de voorbereiding op de nafase: de human factor. Een aanname is dat lokale autoriteiten er belang bij hebben dat een gemotiveerde, capabele kracht in staat is om een samenhangend en werkbaar stelsel van afspraken en plannen op te leveren, waarin allerlei betrokkenen (partners) binnen en 
buiten de gemeente of regio een rol vervullen. Een aanvullende aanname is dat het goed is als die rol op voorhand al eens is uitgedacht op hoofdlijnen, door cruciale principes en uitdagingen al eens met elkaar te bespreken in de context van een scenario dat aansluit bij lokale risico's. Stel dat dit werkelijk zo uitpakt. Dan is de beschikbaarheid van dergelijke mensen ('nafasepreparatieprofessionals') cruciaal, maar onzeker. Er gebeuren te weinig rampen en crises om medewerkers binnen regio en gemeente zelf ervaring en routine te laten verwerven. Dat geldt voor het eenmalig of tijdelijk opzetten van een nafaseorganisatie, maar ook voor de stabiliteit ervan. Wat kan men lokaal doen om te voorkomen dat de preparatie op de nafase afbrokkelt zodra sleutelfiguren buiten beeld raken?

Het individu maakt deel uit van een omgeving. Uiteindelijk spelen individuen een rol in bestuur, (beleids)ondersteuning en uitvoering binnen netwerken van organisaties (zoals gemeenten, hulpdiensten, gezondheidsdiensten, slachtofferhulp, huisartsen en specialistische zorg, maatschappelijk werk en verenigingen): hoe staat het met de voorbereiding van betrokkenen en het samenspel tussen hen?

Tegen deze achtergrond spelen nog andere aspecten. In de praktijk zal de visie van gemeenten en veiligheidsregio's op zelfredzaamheid van burgers en het improvisatievermogen van medewerkers kunnen variëren. Probleemtaxaties en ideeën over al dan niet noodzakelijke oplossingen - of ze nu gebaseerd zijn op mensbeeld, ideologie, gewoonte, smaak of toeval, en al dan niet cultuurgebonden - zullen bepalend zijn voor beslissingen tijdens preparatie en uitvoering. Daarom mogen ze niet worden genegeerd in onderzoek naar de preparatie.

\section{Kwaliteit van nazorg}

Dat brengt ons op het laatste punt. Investeringen in preparatie kunnen naar het publiek en toezichthouders het signaal afgeven dat de lokale overheid haar verantwoordelijkheid neemt. Het zou, in de ogen van een cynicus, een ritualistische vorm van indekken kunnen zijn voor als het eventueel misgaat. Degenen die daarentegen streven naar resultaatgerichtheid en kwaliteitsverbetering hanteren vermoedelijk een ander uitgangspunt, namelijk dat versterking van de preparatie niet alleen ten goede komt aan de structuur, maar ook aan het proces en de uitkomst van de dienstverlening. In vervolgonderzoek kan dit verder worden verkend en kan bovendien de score van de preparatie worden afgezet tegen de resultaten in een daadwerkelijke nafase om een verband te kunnen leggen tussen de planvorming en de resultaten. Dat is misschien wel de belangrijkste vraag binnen dit onderzoeksdomein.

\section{Beperkingen}

Het onderzoek kent een aantal beperkingen. Het gaat om een enkele meting; een momentopname die zich beperkt tot een selectie van nazorgthema's, uitgevoerd in een weliswaar volledige maar niettemin relatief beperkte groep respondenten qua omvang. Een ontwikkeling of mechanisme kon nog niet worden vastgesteld, dat vergt vervolgonderzoek. Omdat er in beperkte mate wetenschappelijke literatuur beschikbaar is over de wijze waarop men in Nederland omgaat met rampen, 
en de nafase in het bijzonder, is ook gebruikgemaakt van algemene literatuur waarin internationale en vooral Amerikaanse ervaringen verwerkt zijn. Wat opvalt, is dat ook internationaal betrekkelijk weinig onderzoek is gedaan naar de preparatie op de nafase van rampen.

\section{Literatuur}

Ammerlaan, V.C. (2009) Na de ramp: de rol van de overheid bij de (schade) afwikkeling van rampen vanuit een belangenperspectief van de slachtoffers. Tilburg: Tilburg University.

Barendse, E. (2008) De kunst van het borgen van resultaten. Rotterdam: Erasmus Universiteit.

Barnes, M., J. Newman, A. Knops en H. Sullivan (2003) Constituting 'the public' in public participation. Public Administration, 81(2), 379-399.

Berghuijs, D. (2000) De toekomst van de rampenbestrijding en het risicomanagement, Een evaluerende rapportage naar aanleiding van de vuurwerkramp in Enschede op 13 mei 2000. Enschede: Commissie Berghuijs.

Bisson, J.I., B. Tavakoly, A.B. Witteveen, D. Ajdukovic, L. Jehel, V.J. Johansen et al. (2010) TENTS guidelines: development of post-disaster psychosocial care guidelines through a Delphi process. British Journal of Psychiatry, 196, 69-74.

Boin, A. en P. 't Hart (2010) Organizing for Effective Emergency Management: Lessons from Research. Australian Journal of Public Administration, 69, 357-371.

Boin, A. en F. Bynander (2015) Explaining success and failure in crisis coordination. Geografiska Annaler: Series A, Physical Geography, 97(1), 123-135.

Bonanno, G.A., C.R. Brewin, K. Kaniasty en A.M. La Greca (2010) Weighing the costs of disaster consequences, risks, and resilience in individuals, families, and communities. Psychological Science in the Public Interest, 11(1), 1-49.

Caem, B. van (2008) Verborgen kracht, burgerparticipatie op het vlak van veiligheid. Amsterdam: Dynamics of Governance.

Douglas, M. en A. Wildavsky (1982) Risk \& Culture. an essay on the selection of technological \& environmental dangers. San Francisco: University of California Press.

Dückers, M., P. Makai, L. Vos, P. Groenewegen en C. Wagner (2009) Longitudinal analysis on the development of hospital quality management systems in the Netherlands. International Journal for Quality in Health Care, 5, 330-340.

Dückers, M.L.A. en I.M.A.M. Pröpper (2011) Zelfredzaamheid in crisistijd. Openbaar Bestuur, Tijdschrift voor beleid, organisatie en politiek, 21(10), 24-28.

Dückers, M., M. Rooze en D. Alexander (2014) Towards resilient organization of recovery and care after disaster. In J.J.L.M Bierens (Ed.), Drowning: Prevention, rescue, treatment. Second Edition. Springer-Verlag.

Dückers, M.L.A. en R. Sardemann (2014) Registratie getroffenen cruciaal voor adequate psychosociale hulp bij rampen en crises. Magazine Nationale Veiligheid en Crisisbeheersing, 12(1), 44-45.

Dückers, M.L.A. en S.B. Thormar (2015) Post-disaster psychosocial support and quality improvement: a conceptual framework for understanding and improving the quality of psychosocial support programs. Nursing \& Health Sciences, 17(2), 159-165.

Dückers, M.L.A., A.B. Witteveen, J.I. Bisson en M. Olff (2015) The association between disaster vulnerability and post-disaster psychosocial service delivery across Europe. Administration and Policy in Mental Health and Mental Health Services Research, 42(4).

Duin, M. van en V. Wijkhuijs (red.) (2014) Lessen uit crisis en mini-crises 2013, Den Haag: Boom Lemma uitgevers. 
Duin, M. van, V. Wijkhuijs en W. Jong (red.) (2013) Lessen uit crisis en mini-crises 2012, Den Haag: Boom Lemma uitgevers.

Duin, M. van en M. Zannoni (2005) Leidraad nafase. Na de ramp ... Den Haag: COT.

Geis, G.L. (1996) Planning and developing effective courses. Teaching on Solid Ground: Using Scholarship to Improve Practice. San Francisco: Jossey/Bass.Gemeente Moerdijk (2014) Vuurdoop, de brand bij Chemie-Pack en wat iedere gemeente ervan kan opsteken. Moerdijk: Gemeente Moerdijk.

Gouweloos, J., J.N. Ten Brinke, M. Sijbrandij, I. Boele en H. te Brake (2013) Bevindingen getroffenen Poldercrash. Diemen: Impact.

Groenewegen-ter Morsche, K. en N. Oberijé (2010) Burgers bij de bestrijding van rampen: betrokken, beschikbaar, bekwaam. Een onderzoek naar praktijkervaringen met burgerparticipatie bij 10 rampen en incidenten in Nederland. Arnhem: Instituut voor Fysieke Veiligheid.

Helsloot, I., E. Oomes en R. Weewer (2009) Eindrapport Evaluatie van de brand in De Punt op 9 mei 2008. Tynaarlo: gemeente Tynaarlo.

Helsloot I. en B. van 't Padje (red.) (2010) Zelfredzaamheid: Concepten, thema's en voorbeelden nader beschouwd. Den Haag: Boom Juridische uitgevers.

Helsloot, I. en M. in 't Veld (2014) Ongerust over onrust. Den Haag: Ministerie van BZK.

Hoijtink, L. en W. Jong (2011) Contact met getroffenen: aandachtspunten voor communicatie tussen overheid en getroffenen in de nafase van rampen en crises. Diemen: Impact.

Holsappel, J., T. Fassaert, T. Dorn en H. te Brake (2013) Quality of psychosocial care: Eindrapport. Diemen/Amsterdam: Impact/GGD Amsterdam.

Kennedy, J., J. Ashmore, E. Babister en I. Kelman (2008) The meaning of 'build back better': evidence from post-tsunami Aceh and Sri Lanka. Journal of Contingencies and Crisis Management, 16(1), 24-36.

Kerstholt, J. (2013) De beslissende burger. Enschede: Universiteit Twente.

Koppenjan, J.F.M. en E.H. Klijn (2004) Managing uncertainties in networks; a network approach to problem solving and decision making. London: Routledge.

Langley, G.J., K.M. Nolan, T.W. Nolan, C.L. Norman en L.P. Provost (1996) The improvement guide: a practical approach to enhancing organizational performance. Jossey-Bass. San Francisco.

Laurier, J.P. en C.E. Brink, J.M.M. de Gouw en E.M.R. Corvers-Debet (2012) Over nazorg en napijn. Alphen aan den Rijn: gemeente Alphen aan den Rijn.

Leferink, S. (2010) Kramp na de ramp, een kritische beschouwing op de hulpverlening bij rampen. Utrecht: Slachtofferhulp Nederland.

Michie, S., M.M. van Stralen en R. West (2011) The behaviour change wheel: a new method for characterising and designing behaviour change interventions. Implementation Science, 6(1), 42.

Muller, E.R, U. Rosenthal, I. Helsloot en E.R.G. van Dijkman (2009) Crisis: studies over crisis en crisisbeheersing, Deventer: Kluwer.

Petterson, J. (1999) A review of the literature and programs on local recovery from disaster. Fairfax: Public Entity Risk Institute.

Pröpper, I. en D. Steenbeek (2001) De aanpak van interactief beleid: elke situatie is anders. Bussum: Coutinho.

Quarantelli, E.L. (1989) How individuals and groups react during disasters: planning and managing implications for EMS delivery. University of Delaware Disaster Research Center.

RMO - Raad voor Maatschappelijke Ontwikkeling (2013) Terugtreden is vooruitzien: maatschappelijke veerkracht in het publieke domein. Den Haag: Raad voor Maatschappelijke Ontwikkeling. 
Rubin, C.B. en D.G. Barbee (1985) Disaster recovery and hazard mitigation: Bridging the intergovernmental gap. Public Administration Review, 57-63.

Scholtens, A.C.J. (2007) Samenwerking in crisisbeheersing: Overschat en onderschat. Arnhem: Nederlands Instituut Fysieke Veiligheid (Nibra).

Smith, G. (2010) Lessons from the United States: planning for post-disaster recovery and reconstruction. The Australasian Journal of Disaster and Trauma Studies, 1, 1-8.

Taylor, M.J., C. McNicholas, C. Nicolay, A. Darzi, D. Bell en J.E. Reed (2014) Systematic review of the application of the plan-do-study-act method to improve quality in healthcare. BMJ quality \& safety, 23(4), 290-298.

Terpstra, J.B. en R.M. Kouwenhoven (2004) Samenwerking en netwerken in de lokale veiligheidszorg. Zeist: Kerckebosch.

Wagner, C. (1999) Implementation and effectiveness of quality systems in Dutch health care organization. Utrecht: NIVEL.

Zannoni M. (2010) En nu...? Handboek voor de nafase van incidenten, rampen en crises. Den Haag: Boom Juridische uitgevers.

\section{Wetsteksten}

Besluit Veiligheidsregio's (2010): art. 2.1.3, lid c.

Wet Publieke Gezondheid (2008): art. 2.

Wet Veiligheidsregio's (2010): art. 14-16.

\section{Rapporten}

Bevolkingszorg op Orde, de vrijblijvendheid voorbij (2012): Arnhem, Veiligheidsberaad (red. P. Bruinooge et al.).

Grooter (2012): Arnhem, Veiligheidsberaad.

Handreiking regionale implementatie SIS (2013): Arnhem, Veiligheidsberaad.

Multidisciplinaire Richtlijn psychosociale hulp bij rampen en crises (2014): Diemen, Impact.

Richting geven aan de laatste schakel (2012): Den Haag, Ministerie van Veiligheid en Justitie.

Task Force Management Overstromingen (2009): Rapport van bevindingen. Den Haag, TMO. 